\title{
The Essential Role of Empirical Analysis in Developing Law and Economics Theory
}

\author{
Jennifer Arlen ${ }^{\dagger}$
}

Throughout its history, the development of theoretical law and economics has depended on, and been shaped by, empirical analyses of law. Theoretical law and economics scholars cannot draw persuasive positive or normative conclusions about legal rules unless the models employed accurately capture the factors affecting people's responses to legal rules. Models thus must accurately describe decision-makers' decision-making environment, available choices, and decision-making processes. Empirical analysis plays a vital role in theoretical scholars' ability to develop such models. Empirical analyses can improve theoretical models by testing the predictions of models; refuted theoretical predictions regularly spur lead theoreticians to revise and improve their models. Empirical analyses also contribute by providing direct evidence on the decision-making environment, available choice sets, or decision-makers' mental processes. This interaction of empirical analysis and theory has led theoretical law and economics to rely increasingly on models predicated on incomplete information, incomplete contracting, and decision-making that deviates from rational choice theory.

Introduction 481

I. Rational Choice and Theoretical Law and Economics .................484

II. Contributions of Empirical Analyses to Theoretical Law and

Economics 486

A. Evidence About the Informational Environment...............487

1. Empirical Evidence Bearing on Normative Implications of Existing Theory....

2. Empirical Evidence Inducing Changes to the Information Structure of Theoretical Models

B. Evidence Prompting Expansion of the Potential Set of Options

$\dagger \quad$ Norma Z. Paige Professor of Law and Faculty Director of the Program on Corporate Compliance and Enforcement, New York University School of Law and co-founder of the Society of Empirical Legal Studies. This Essay was prepared for the conference on New Challenges for Law and Economics. I would like to thank participants at the conference for their helpful comments on this Essay, as well as Emiliano Catan, Barton Beebe, Hanoch Dagan, Jeannie Fromer, Tami Kricheli-Katz, Florencia Marotta-Wurgler, and Robert Scott. 


\section{From Rational Choice to Behavioral Law and Economics and

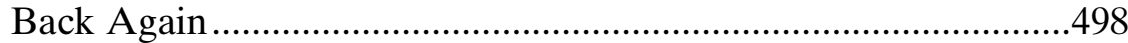

Conclusion

Introduction

Throughout its history, the development of theoretical law and economics has depended on, and been shaped by, empirical analyses of law. ${ }^{1}$ Theoretical law and economics seeks to achieve one of two goals. Positive analyses aim to describe, and in turn predict, legal rules' effect on people's choices. Normative analyses strive to determine optimal legal rules by employing models that designed to describe people's responses to different legal rules. The validity of both efforts depends on whether their models ${ }^{2}$ accurately predict people's choices. Thus, positive and normative theoretical law and economics must employ models that capture the features of the actual decision-making environment (for example, access to information), the actual available choice sets, and the decision-makers' choice processes likely to materially impact people's choices. ${ }^{3}$

Empirical analysis of law plays a vital role in helping theoretical scholars develop models designed to have the "fit" needed to both predict the effect of legal rules and serve as a foundation for normative policy. ${ }^{4}$ It does

1. Throughout this Essay, the term "empirical analysis of law" refers to all studies that apply replicable methodology to analyze evidence relating to a legal issue. Thus, the term can encompass regression analysis of large datasets, experimental studies, analysis of survey data, and observational studies.

2. Throughout this Essay the term "model" is used to refer to both formal models and informal analysis predicated on a set of assumptions, whether explicit or implicit, about the decision-making environment, the choice set, and the decision-making programs people use to make choices.

3. The fit between the model and the real world tends to be more important to theoretical law and economics than to pure economic theory. Economic theory often seeks to identify how a particular feature of a decision-making environment-e.g., asymmetric information-impacts choices. Economists can appropriately use what Paul Pfleiderer refers to as "bookshelf" models, which are designed to analyze how a particular set of assumptions impacts behavior, but do not seek to describe decision-making in the real world. By contrast, positive and normative theoretical law and economics generally seek to predicate how legal rules affect behavior in the real world. Thus, just as empirical economists seeking to describe actual behavior need to ground their analyses on theories that accurately capture the situation they seek to analyze, descriptive and normative theoretical law and economics also must employ models that seek to capture the features of the decision-making environment, the choices sets, and decision-makers' processes likely to materially impact choices. See Paul Pfleiderer, Chameleons: The Misuse of Theoretical Models in Finance and Economics, 87 ECONOMICA 81 (2020) (discussing empirical economists' work).

4. Empirical analyses enrich theoretical law and economics only to the extent that the empirical studies themselves are valid. Thus, prior to relying on an empirical study, theoretical scholars should assess its validity. For example, they should determine whether the study rests on a valid theoretical foundation that reflects an appropriate understanding of legal and contractual institutions. See, e.g., Pfleiderer, supra note 3. Empirical analyses identifying weaknesses in prior empirical studies' assumptions regarding the legal or contractual landscape include Robert P. Bartlett III, Going Private but Staying Public: Reexamining the Effect of Sarbanes-Oxley on Firms' Going-Private Decisions, 76 U. CHI. L. REV. 7 (2009); Emiliano M. Catan \& Marcel Kahan, The Law and Finance of Antitakeover Statutes, 68 STAN. L. REV. 629 (2016); and Holger Spamann, The "Antidirector Rights Index" Revisited, 23 REV. FIN. STUD. 467 (2010). Theoretical 
so by improving theorists' understanding of, and ability to correctly characterize, the informational, contractual, institutional, and legal environment affecting decision-makers, as well as the decision-making processes that people employ. Empirical analysis can assist theorists both directly and indirectly.

Empirical studies can aid theoretical analysis directly by providing empirical evidence on the material features of a particular decision-making environment. For example, empirical analysis can reveal that, contrary to theory, decision-makers regularly do not have the information they need to make material decisions. Empirical analysis also can enable better modeling of people's actual decision-making processes.

Empirical analysis also can affect theoretical analysis indirectly by testing the predicted outcomes of theoretical models. Studies showing that actual outcomes deviate from predicted outcomes can and have led scholars to identify features of the decision-making environment, and of decision-makers themselves, that differ materially from those that previously served as the foundations for theoretical analysis.

Of course, the simple fact that a theoretical model deviates from the real world does not suffice to justify its revision. A good law and economics model removes extraneous complexity in an effort to focus on those features of the decision-making environment that are both material to people's decision-making and are potentially affected by the legal rule being examined. Yet, while theoretical models need not, and should not, incorporate every aspect of the real world in order to predict how people will respond to a legal rule, models should accurately reflect those features of the actual decision-making environment, the choice set, and the decision-

scholars also should assess datasets employed. Analyses highlighting limitations of popular datasets include Cindy R. Alexander et al., Evaluating Trends in Corporate Sentencing: How Reliable Are the U.S. Sentencing Commission's Data?, 13 FED. SENT'G REP. 108 (2000): Eric Helland et al., Data Watch: Torturing the Data, 19 J. ECON. PERSP. 207 (2005); and Jonathan M. Karpoff et al., Proxies and Databases in Financial Misconduct Research, 92 ACCT. REV. 129 (2017). Finally, theoretical scholars should attend to the appropriateness of the empirical methodology employed bearing in mind previously identified methodological issues. E.g., William Anderson \& Martin T. Wells, A Bayesian Hierarchical Regression Approach to Clustered and Longitudinal Data in Empirical Legal Studies, 7 J. EMPIRICAL LEGAL STUD. 634 (2010); Robert Bartlett \& Frank Partnoy, The Misuse of Tobin's q, 73 VAND. L. REV. 353 (2020); Marianne Bertrand et al., How Much Should We Trust Differences-in-Differences Estimates?, 119 Q.J. ECON. 249 (2004); A. Colin Cameron et al., Bootstrap-Based Improvements for Inference with Clustered Errors, 90 ReV. ECON. \& STAt. 414 (2008); see Theodore Eisenberg et al., Addressing the Zeros Problem: Regression Models for Outcomes with a Large Proportion of Zeros, with an Application to Trial Outcomes, 12 J. EMPIRICAL LEGAL STUD. 161 (2015); Jill E. Fisch et al., The Logic and Limits of Event Studies in Securities Fraud Litigation, 96 TEX. L. REV. 553 (2018); Jonah B. Gelbach, Valid Inference in Single-Firm, Single-Event Studies, 15 AM. L. \& ECON. REV. 495 (2013); Emiliano M. Catan \& Michael Klausner, Board Declassification and Firm Value: Have Shareholders and Boards Really Destroyed Billions in Value? (N.Y.U. Law \& Econ. Research Paper No. 17-39, 2017) (highlighting the importance of controlling for underlying trends to difference-in-difference analysis), https://ssrn.com/abstract=2994559 [https://perma.cc/AUC9-83M7]; see also Saul Levmore, The Eventual Decline of Empirical Law and Economics, 38 YALE J. ON REG. 612 (2021). 
making processes that are material to, and systematically influence, people's choices. Thus, theorists should presumptively incorporate into their analyses empirical evidence revealing that the actual decision-making environment differs from the assumptions of their models if either economic theory suggests the differences are material or empirical analysis finds that existing theory does not reliably predict actual outcomes. In turn, theorists should presumptively alter their models in response to evidence that actual outcomes deviate from predicated outcomes if either observation or empirical evidence suggests that a core assumption of the model is not valid.

The history of theoretical economic analysis of law is replete with instances where empirical analysis revealed that a widely embraced economic model needed to be revised. This Essay examines a few of the ways in which empirical analysis has led to improvements in theoretical economic analysis of law by providing results that were contrary either to fundamental assumptions or predicted outcomes of existing models. ${ }^{5}$ This Essay focuses on analyses that revealed important imperfections in individuals' information sets and in their ability to address economic problems through contracts that materially affected both the predictive and normative conclusions of theoretical analysis. It also discusses empirical evidence on people's decision-making processes that affects outcomes, including evidence on how institutions (such as organizations) affect decisions. This Essay shows that empirical analysis, in concert with advances in economic theory, has led theoreticians to develop more sophisticated mod-

5. This Essay focuses on how empirical analysis has enriched theoretical models by improving scholars' understanding of decision-making environments, the available choice set, and the decision-making processes employed. These are only a subset of the many ways that empirical analysis can contribute to theoretical law and economics. For example, empirical analysis has revealed that the law affects behavior not only through the sanctions imposed but also through its expressive function - its ability to express society's view that certain actions are socially harmful or immoral. E.g., Symposium, How Law Changes What You Want: Positive and Normative Effects of Law on Values and Preferences, THEORETICAL INQUIRIES L. (forthcoming 2021) (exploring this literature); see also Hanoch Dagan et al., Legal Theory for Legal Empiricists, 43 L. \& SOC INQUIRY 292 (2018) (discussing the variety of ways that the law induces legal compliance). Empirical analysis by legal scholars, sociologists, organizational theorists, psychologists and others also contributes by improving our understanding of the plethora of ways in which institutions affect behavior - both by directly altering people's decision-making and by providing alternative methods for regulating and coordinating certain transactions. See, e.g., ROBERT C. ELLICKSON, ORDER Without LaW: How NeIGHBORS SETTLE DisPuTES (1991); Jennifer Arlen \& Stephan Tontrup, Does the Endowment Effect Justify Legal Intervention? The Debiasing Effect of Institutions, 44 J. LEGAL STUD. 143 (2015) (showing how involving agents or voting in the decision to trade mutes the endowment effect triggered by regret aversion); Björn Bartling \& Urs Fischbacher, Shifting the Blame: On Delegation and Responsibility, 79 REV. ECON. STUD. 67 (2012) (showing how using agents to divide resources mutes responsibility thereby facilitating unfair allocations); Lisa Bernstein, Private Commercial Law in the Cotton Industry: Creating Cooperation Through Rules, Norms, and Institutions, 99 MICH. L. REV. 1724 (2001); Lisa Bernstein, Opting out of the Legal System: Extralegal Contractual Relations in the Diamond Industry, 21 J. LEGAL STUD. 115 (1992). Empirical analysis also may enrich our understanding of people's preferences regarding the appropriate goals of their legal or political institutions. See, e.g., Tamar Kricheli Katz, Response to Jennifer Arlen on The Essential Role of Empirical Analysis in Developing Law and Economics Theory, 38 YALE J. ON REG. BULL. 154 (2021). 
els. These models tend to focus on decision-making in environments characterized by incomplete information and incomplete contracts, and to reflect evidence that people's decision-making can deviate from rational choice.

This Essay proceeds as follows. Part I discusses the basic structure of classic law and economic models of legal rules predicated on rational choice, identifying features of those models particularly amendable to insights from empirical analysis. Part II discusses illustrative examples in the areas of consumer contracts, medical malpractice liability, and takeovers in which empirical analysis has either spurred the development of new models or altered the normative implications of existing models, while retaining rational choice theory. ${ }^{6}$ Part III discusses how empirical analysis of human decision-making has spurred theoreticians to incorporate alternative models of decision-making from rational choice, and the challenges posed by such evidence in the effort to develop accurate models of how legal rules affect behavior. Part IV concludes.

\section{Rational Choice and Theoretical Law and Economics}

Theoretical law and economics generally relies on rational choice models both to examine the effect of legal rules and determine optimal laws. Rational choice models share a particular structure: actors with predetermined preferences over the available options each selects the option that maximizes her welfare (given her preferences). In these models, each actor's choices are affected by her preferences (which are assumed to be fixed), the set of options or strategies available to her, the expected costs and benefits to her of each option. The expected costs and benefits of each option in term depends in part on the information available, how legal rules affect each option, and, in some situations, other people's expected behavior. ${ }^{7}$ Rational choice models thus seek to predict individuals' behavior in a specific decision-making environment having specified each individual's decision-making function and decision-making environment. This analysis serves as the foundation for normative policy prescriptions.

Theoretical law and economics employs formal and informal models to explore how legal rules can alter behavior by altering either the options available to people ${ }^{8}$ or the actual or perceived ${ }^{9}$ costs or benefits of the

6. See, e.g., Jon Doyle, Rational Decision Making, in THE MIT ENCYCLOPEDIA OF THE COGNITIVE SCIENCES 701 (Rob A. Wilson \& Frank Keil eds., 1999); ANDREU MAS-COLELl ET AL., MiCROECONOMIC THEORY (1995).

7. See, e.g., Jennifer Arlen \& Lewis Kornhauser, Can the Law Change Preferences?, THEORETICAL INQUIRIES L. (forthcoming 2021).

8. For example, laws that allow (or disallow) contracts with liquidated damages clauses, or that preclude doctors from contracting over malpractice liability, alter the choices available to contracting parties.

9. Laws can alter the information available to people, thereby altering either their or other people's understanding of the consequences of their actions or the set of optimal contract 
available options. For example, criminal laws directly increase the costs of taking the actions the law prohibits by threatening to sanction those who engage in the prohibited action. ${ }^{10}$ Medical malpractice liability also alters the perceived cost of options; it also restricts the options available by prohibiting an option: contracting over liability. ${ }^{11}$

Theoretical models cannot effectively predict the effect of legal reform or identify optimal legal rules unless they accurately capture the features of people's actual decision-making environment that materially affect their choices. Thus, theoretical analysis needs to represent the decision-making environment with sufficient accuracy that the choices that maximize actors' preferences in the theoretical model align with those that maximize actors' preferences in the real world situation that the analysis seeks to model. ${ }^{12}$ A model cannot effectively predict how laws will affect behavior or help to identify rules that maximize people's welfare if the choices that maximize actors' welfare in the model differ from those that people prefer in the real world, given their actual available information, available choices, and the perceived costs and benefits of those choices.

Accordingly, theoretical analyses that aspire to predict people's responses to legal rules must accurately represent the material aspects of the decision-making environment that affect people's responses to legal rules. They must correctly reflect the options available (the choice set), the information available (and its cost), the effect of the law on the expected costs and benefits of any options impacts, and individuals' decision-making processes. In some cases, theoretical scholars can identify the key features

terms that parties can implement. For example, laws can alter beliefs by mandating disclosure that provides consumers with additional information on the riskiness of individual producer's products. Alternatively, laws may facilitate contracting between principals and agents by requiring agents to inform principals about self-dealing or conflict of interest transactions.

10. Laws also can alter the consequences of specific actions in other ways, however, and theoretical scholars have developed analyses designed to examine these channels. For example, laws also can change the consequences of taking specific actions by changing the "social meaning" of the action, thereby either changing the "internal" consequences to the actor of the action or changing the external consequences through the impact on how others treat those who engage in the option. See, e.g., Robert Cooter, Expressive Law and Economics, 27 J. LEGAL STUD. 585 (1998); Kenneth G. Dau-Schmidt, An Economic Analysis of the Criminal Law as a PreferenceShaping Policy, 1990 DuKE L.J. 1, 22-23; Lawrence Lessig, The Regulation of Social Meaning, 62 U. CHI. L. REV. 943 (1995); Richard H. McAdams, A Focal Point Theory of Expressive Law, 86 VA. L. REV. 1649 (2000); Cass R. Sunstein, On the Expressive Function of Law, 144 U. PA. L. REV. 2021 (1996); see also Arlen \& Kornhauser, supra note 7 (discussing how expressive law theories align with rational choice theory).

11. Cases invalidating exculpatory clauses in contracts between physicians or hospitals and patients include: Tunkl v. Regents of Univ. of Cal., 383 P.2d 441, 446-47 (Cal. 1963); Smith v. Hosp. Auth., 287 S.E.2d 99 (Ga. Ct. App. 1981); Cudnik v. William Beaumont Hosp., 525 N.W.2d 891, 895-896 (Mich. Ct. App. 1994); Ash v. N.Y. Univ. Dental Ctr., 564 N.Y.S.2d 308 (App. Div. 1990).

12. This is not to say that the model needs to accurately reflect every input into the decision. This is neither possible nor desirable. But a model should capture those aspects of the law, the decision-making environment, the available choice set, and individuals' decision-making processes that systematically affect outcomes in the situation being studied. See supra note 3 (comparing theoretical law and economics and pure economics theory). 
of the decision-making environment based on casual observation. But often theorists need the insights provided by empirical analyses.

Empirical analyses can benefit theoretical models in two ways. First, and most obviously, empirical analyses can test theorists' predictions to determine whether actual behavior conforms to the predictions of the model. Evidence from valid empirical analyse ${ }^{13}$ that actual behavior deviates materially from the prediction of the model generally suggests that the model did not accurately capture a material feature of the decision-making environment, the decision-makers, or the law itself. ${ }^{14}$

Second, empirical analysis can provide direct evidence about the appropriate assumptions to incorporate into theoretical models. Empirical analysis can do this by providing evidence about people's available information, options, or the consequences to people of different options. Theorists do not always need to modify models in response to evidence that the real world differs from the assumptions of the model. Yet they do need to do so if evidence reveals that the decision-making environment diverges from the assumptions employed in the models and either empirical evidence finds that people's actual choices diverge from the predictions of the model or economic theory suggests that altering to model to better represent the actual decision-making environment would have a material effect on agents' choices.

Throughout law and economics history, empirical analysis has helped to improve theoretical analysis through both of these channels. In so doing, empirical analysis has helped lead to theories that are better able to predict behavior. It also has improved the theoretical frameworks used as a basis for normative predictions.

\section{Contributions of Empirical Analyses to Theoretical Law and \\ Economics}

This Part provides some illustrative examples of how empirical analysis has led to insights that enriched and arguably improved law and economics theory. The interplay between empirical analysis and theory dates back to the earliest days of the development of law and economics. As a result, there are more examples than can be considered in this Essay. This Part selects only a few examples of how empirical analysis has prompted changes to theoretical models that yielded new insights.

13. See supra note 4

14. This presumption does not apply, however, if the empirical analysis itself is fraught with issues, such as data limitations, endogeneity problems or omitted variables. Moreover, empirical analysis on outcomes of existing law often is not a good measure of the validity of models of optimal laws, unless the models of optimal laws identify laws that conform to the existing law tested in the study. 
The Essential Role of Empirical Analysis

\section{A. Evidence About the Informational Environment}

\section{Empirical Evidence Bearing on Normative Implications of Existing Theory}

One of the most fundamental normative issues in law and economics is determining situations under which government need not regulate an activity that risks harm to others because the potential injurer and victims can optimally address the risk through private arrangements, such as contracts or market forces. ${ }^{15}$

Ronald Coase famously observed that the existence of externalities does not suffice to justify legal intervention. ${ }^{16}$ Legal intervention is only needed when the parties involved-for example, an injurer and a potential victim in a tort case or two contracting parties in a contracts case-cannot induce optimal risk reduction through private means. Coase focused on the impediment that transactions costs pose for optimal regulation through private arrangements. Subsequent scholars analyzing product liability and medical malpractice identified imperfect information as a source of inefficiency undermining private action, and thereby justifying government intervention. They concluded that liability was not needed in order to induce producers and medical caregivers to take optimal care and undertake the optimal level of the activity if consumers are perfectly informed about the risks of the product. ${ }^{17}$

The claim that contractual liability could be optimal was further strengthened by theoretical models showing that contracting over liability would induce producers to invest optimally in care, even if consumers do not know product risks, if consumers know the costs and deterrence benefits of imposing liability by contract. ${ }^{18}$ Scholars claims that in this situation the parties have optimal incentives to impose liability by contract. ${ }^{19}$ This latter claim does not require consumers and patients to know the expected

15. See R.H. Coase, The Problem of Social Costs, 3 J.L. \& ECON. 1 (1960).

16. Id.

17. Kenneth J. Arrow, Uncertainty and the Welfare Economics of Medical Care, 53 AM. ECON. ReV. 941 (1963); Michael Spence, Consumer Misperceptions, Product Failure and Producer Liability, 44 ReV. ECON. STUD. 561 (1977); see A. Mitchell Polinsky, Strict Liability vs. Negligence in a Market Setting, 70 AM. ECON. REV. 363 (1980); Steven Shavell, Strict Liability Versus Negligence, 9 J. LEGAL STUD.1 (1980).

18. The argument that contracting over liability could be efficient even if people cannot assess quality differences in individual providers is particularly important to the debate over malpractice liability given the wealth of evidence that patients cannot assess either the differences in expected outcomes of obtaining services from one hospital or provider versus another or the appropriateness of treatments provided to them. See, e.g., Jennifer Arlen \& W. Bentley MacLeod, Malpractice Liability for Physicians and Managed Care Organizations, 78 N.Y.U. L. REV. 1929, 1938-29 \& n. 67 (2003) (discussing evidence that patients lack information to assess the quality of care they are provided).

19. Sanford J. Grossman, The Informational Role of Warranties and Private Disclosure About Product Quality, 24 J.L. \& ECON. 461 (1981); George L. Priest, A Theory of Consumer Product Warranty, 90 YALE L.J. 1297 (1981). 
harm associated with individual producers. But, among other requirements, consumers and patients must know the terms of the contracts presented to them in the standard form contracts offered to them by producers or medical providers and must know how liability would alter their expected risk of harm. ${ }^{20}$

Both theory and anecdotal evidence suggests that this informational requirement often is not satisfied. For one, it often is optimal for consumers and patients to not to read standard form contracts. ${ }^{21}$ In this case, market forces would not lead to efficient contracting over liability. Moreover, the observation that people often optimally do not read standard form contracts also potentially implies that legal intervention might be needed to police substantive contract terms in standard form contracts, in order to safeguard consumers from abusive contract terms.

In an important article, Alan Schwartz and Louis Wilde proposed a clever solution to this impediment to optimal contractual liability. They showed that even if most consumers do not read standard form contracts, market forces nevertheless could provide producers with incentives to offer optimal contractual liability terms if a sufficiently large minority of those consumers whose willingness to pay is sensitive to contract terms do read, and are informed the effects of, the liability terms in contracts. ${ }^{22}$ This claim that standard form contracting can be rendered efficient by an informed minority was embraced by scholars in a variety of areas to argue against legal regulation of contracts. ${ }^{23}$

Yet this argument that contracting is efficient ${ }^{24}$ only holds if the percentage of informed quality-sensitive consumers is sufficiently large that producers are better off offering higher quality (and higher cost) contract

20. In addition, consumers must understand how contracting into liability affects their expected risk of harm. This requirement is rarely satisfied. See Jennifer Arlen, Private Contractual Alternatives to Malpractice Liability, in MEDICAL MALPRACTICE AND THE U.S. HEALTH CARE SYSTEM 245 (William M. Sage \& Rogan Kersh eds., 2006); Mark Geistfeld, The Political Economy of Neocontractual Proposals for Products Liability Reform, 72 TEX. L. REV. 803 (1994). Moreover, contractual liability can be inefficient even when consumers are informed. See infra notes 4344 and accompanying text.

21. Avery Wiener Katz, Stanford Form Contracts, in THE NEW PALGRAVE DICTIONARY OF LAW AND ECONOMICS 1902 (Peter Newman ed., 1998); Lewis A. Kornhauser, Comment, Unconscionability in Standard Forms, 64 CALIF. L. REV. 1151, 1183 (1976) (discussing inefficiencies plaguing standard form contracting); see Marcel Kahan \& Michael Klausner, Standardization and Innovation in Corporate Contracting (or "The Economics of Boilerplate"), 83 VA. L. REV. 713, 729-35 (1997) (noting learning and network externalities can lead to inefficient contracts).

22. Alan Schwartz \& Louis L. Wilde, Intervening in Markets on the Basis of Imperfect Information: A Legal and Economic Analysis, 127 U. PA. L. REV. 630 (1979).

23. E.g., Douglas G. Baird, The Boilerplate Puzzle, 104 MICH. L. REV. 933 (2006); Howard Beales, Richard Craswell \& Steven C. Salop, The Efficient Regulation of Consumer Information, 21 J.L. \& ECON. 491 (1981); Clayton P. Gillette, Rolling Contracts as an Agency Problem, 2004 WIS. L. REV. 679.

24. The informed minority argument only addresses one of the many ways in which contracts can be inefficient. See infra notes 43-44 and accompanying text (explaining contractual liability can be inefficient even when consumers know the costs and benefits of contracting over liability). 
terms to everyone in order to retain the informed minority. It does not hold if they would fare better employing lower cost suboptimal contracts that only the uninformed majority will accept, but the informed minority will reject, because the additional profit over those consumers who accept the suboptimal contract exceeds the loss of business with the small number of information consumers.

Thus, Schwartz and Wilde's claim about the efficiency of contractual liability depends on an empirical fact: whether the percentage of consumers who read and fully understand particular standard form contracts is sufficiently large to motivate producers to offer optimal, but costlier, contracts in order to retain them. This question is best answered with empirical evidence.

Empirical scholars have provided this evidence. Their findings do not support the optimality of standard form contracting. An important study of end-user license agreements provides evidence that, at least in that area, if not others, there are too few informed consumers to exert any market discipline on contract terms. An examination of clickstream data from over 48,000 consumers of 90 online software companies found that only 1-2 out of every 1,000 consumers (or 0.1-0.2\%) accessed the contract terms. Moreover, most of those people only read a small portion of the contract. ${ }^{25}$ This evidence that only a small percentage of online consumers read standard form contracts has broader implications because the costs to consumers of accessing and reading these agreements is quite low-lower than say the cost of reading through the extensive standard form contracts that hospitals require patients to sign as a prerequisite to getting treatment. This evidence thus arguably suggests that one cannot assume that an adequate informed minority exists - at least absent convincing evidence that it does. This result contributes to theory by altering the justifiable assumptions that can be made about whether there exists an adequately large informed minority, thereby altering both the predictions and normative conclusions of the existing theoretical models. ${ }^{26}$

25. Yannis Bakos et al., Does Anyone Read the Fine Print? Consumer Attention to Standard-Form Contracts, 43 J. LEGAL STUD. 1 (2014). Moreover, those consumers who do access the contract spend far too little time reading it to read it completely or digest its material terms. Id.; see Florencia Marotta-Wurgler, Even More Than You Wanted to Know About the Failures of Disclosure, 11 JERUSALEM REV. LEgAL STUD. 63, 66-70 (2015); Florencia Marotta-Wurgler \& Robert Taylor, Set in Stone? Change and Innovation in Consumer Standard-Form Contracts, 88 N.Y.U. L. REV. 240 (2013) (highlighting the trend towards longer and more complex standard form consumer contracts).

26. Evidence that people do not read standard form contracts is one of the reasons that Omri Ben-Shahar and Carl E. Schneider conclude that other interventions tend to be superior to mandatory disclosure. OMRI BEN-SHAHAR \& CARL E. SCHNEIDER, MORE THAN YOU WANTED TO KNOW: THE FAILURE OF MANDATED DISCLOSURE (2010). 


\section{Empirical Evidence Inducing Changes to the Information Structure of Theoretical Models}

In addition to altering the policy implications of existing theories, empirical analyses can provide insights that motivate theorists to alter their theoretical models in ways that alter both predictive and normative conclusions. For example, economic models of medical malpractice have evolved to reflect insights from empirical analysis about the information environment affecting medical providers' and patients' choices.

Law and economics analysis of medical malpractice has its roots in the classic law and economics models of torts involving victims and injurers in consensual relationships (for example, products liability). In these models, a potential injurer (here the doctor) provides a service to the potential victim (here the patient) that can harm the victim. The expected harm depends on choices made by the injurer. The victim does not have sufficient information about the potential injurer's actions to either assess expected harm or optimally regulate the injurer's behavior by contract. ${ }^{27}$

This model implies that, absent liability, medical markets are not efficient because physicians do not have adequate incentives to incur costs to improve patients' expected welfare since patients cannot assess quality differences in either providers or treatment choices.$^{28}$ This classic model concludes that negligence liability could induce physicians to provide the optimal treatment so long as the standard of care is set at the optimal treatment and expected damages equal the victim's harm.

According to the classic model, optimal tort liability eliminates all risk to patients of being harmed by negligent treatment. This model also implies that super-compensatory damages would not cause physicians to take excessive care as long as courts set due care correctly, because physicians can avoid any risk of excessive damages by taking due care. ${ }^{29}$

Yet the conclusion that injurers will not be negligent in equilibrium is inconsistent with empirical evidence that patients face a material risk of being harmed by negligent treatment. ${ }^{30}$ This evidence suggests that the

27. The formal models of tort liability governing voluntary relationships focus on products liability. E.g., Spence, supra note 17; Polinsky, supra note 17; Shavell, supra note 17. Law and economics scholars also apply these models to medical malpractice. See infra note 42.

28. See, e.g., Arlen \& MacLeod, supra note 18; Arrow, supra note 17, at 951.

29. Robert Cooter, Prices and Sanctions, 84 Colum. L. REV. 1523 (1984); see Shavell, supra note 17. Super-compensatory damages could induce injurers to take excessive care if courts err, unless either causation rules eliminate the discontinuity under negligence, Marcel Kahan, Causation and Incentives to Take Care Under the Negligence Rule, 18 J. LEGAL STUD. 427 (1989), or the errors substantially favor the defendant, Richard Craswell \& John E. Calfee, Deterrence and Uncertain Legal Standards, 2 J.L. ECON. \& ORG. 279 (1986), as is likely with medical malpractice cases. See, e.g., David M. Studdert et al., Claims, Errors, and Compensation Payments in Medical Malpractice Litigation, 354 NEw ENG. J. MED. 2024 (2006).

30. E.g., Paul C. Weiler et Al., A Measure of Malpractice: Medical injury, MALPRACTICE LiTIGATION, AND PATIENT COMPENSATION 43-44 (1993) (finding that $3.7 \%$ of hospital patients were victims of an error that caused significant harm based on a review of written 
model does not accurately predict the operation of the tort system. It does not indicate whether or how the model should be modified, however. For example, the model makes several assumptions about how the tort system operates that are not realistic. It assumes that damages equal the social cost of the harm, when in fact tort damages for death and injury are substantially less than the social cost of the harm caused. ${ }^{31}$ It also assumes that negligent injurers are always held liable, whereas negligent physicians are rarely held liable. ${ }^{32}$ Yet these differences with the actual tort system do not necessarily imply that normative theorists should alter their models. Instead, they indicate that legislatures should reform the tort system.

Yet these are not the only ways in which the classic model deviates from the real world. Empirical evidence on medical error reveals that a central assumption of the classic model about injurers' decision-making environment is inconsistent with physicians' actual decision-making environment. The classic model assumes that injurers are fully and costlessly informed about the appropriate level of care. It assumes that each physician is fully informed about the costs and benefits of the available treatments and is in complete control of whether she is negligent or non-negligent. As a result, a physician always knows when she is negligent. There is no accidental or unintended medical negligence. All negligence is deliberate. ${ }^{33}$

In actuality, physicians regularly are not fully and costlessly informed about either the nature of the patient's condition or the optimal treatment. Instead, they must incur costs (both before and after meeting the patient) to obtain information (hereinafter expertise) needed to properly diagnose patients and identify and provide the optimal treatment. Moreover, physicians who optimally invest in expertise nevertheless may not be sufficiently informed to properly diagnose and treat the patient. As a result, physicians can unintentionally provide the wrong treatment believing it to be correct. Indeed, empirical studies find that inadequate knowledge is a leading cause of medical error. ${ }^{34}$ Thus, in contrast to the classic model in which all negligence is deliberate, the empirical evidence finds that a substantial portion

hospital records); Elizabeth A. McGlynn et al., The Quality of Health Care Delivered to Adults in the United States, 348 NEW ENG. J. MED. 2635, 2641 (2003) (finding that patients on average receive only about $55 \%$ of recommended care).

31. See, e.g., Jennifer H. Arlen, Note, An Economic Analysis of Tort Damages for Wrongful Death, 60 N.Y.U. L. REV. 1113, 1114 (1985).

32. Patients who are injured by medical negligence rarely sue their doctors. E.g., David M. Studdert et al., Negligent Care and Malpractice Claiming Behavior in Utah and Colorado, 38 MED. CARE 250, 255 (2000) (finding that ninety-seven percent of the patients injured by medical negligence did not sue). When they do sue, they often lose. See Paul C. Weiler, Medical MALPRACTICE ON TRIAL 12-13 (1991) (finding that only one in three victims of medical error who suffered serious injuries were awarded damages).

33. See, e.g., Shavell, supra note 17.

34. E.g., Michelle M. Mello \& David M. Studdert, Deconstructing Negligence: The Role of Individual and System Factors in Causing Medical Injuries, 96 GEO. L.J. 599, 606 tbl.1 (2008) (finding that forty-eight percent of medical errors that produced a claim were attributable, at least in part, to the physician's lack of technical competence or knowledge); see also ATUL GAWANDE, COMPLICATIONS: A SURGEON'S NOTES ON AN IMPERFECT SCIENCE 197-98 (2003) (discussing 
of medical negligence is accidental, resulting from inadequate information. The risk of accidental error is endogenous - each physician can reduce it by investing more in expertise.

Empirical analysis thus reveals that, in order to induce physicians to provide optimal care, the tort system has to regulate two quite different decisions. It needs to ensure that informed physicians have optimal incentives to select and provide the optimal treatment when informed. In addition, the tort system needs to provide physicians with optimal incentives to invest in the information needed to be able to determine and provide optimal care (expertise).

The tort system regulates these two types of care through liability imposed for two different forms of negligence. Under the tort system, the due care determination is predicated on treatment choice; courts do not (and cannot) take into account whether, over a physician's career, the physician invested optimally in expertise. Thus, the tort system regulates treatment choice directly through the due care standard, which imposes liability on physicians who harm a patient by providing negligent treatment. The threat of liability for negligence can be used to ensure that physicians who are informed about the optimal treatment select it, instead of providing less expensive suboptimal treatment. Physicians' incentives to invest in expertise is determined by the threat of liability for accidental medical error-liability that physicians can reduce, but not eliminate, by investing optimally in expertise. ${ }^{35}$

Thus, empirical evidence about the sources of medical error reveals both an additional goal for tort liability - regulation of investment in expertise - and an additional pathway through which it impacts behaviorliability for accidental error. Accordingly, in order to make normative policy prescriptions that reflect the purposes and effects of tort liability, we need to alter the theoretical model to more accurately describe the physician's informational environment and choice set. ${ }^{36}$

Theorists have developed a model of medical malpractice in which physicians take two different forms of care: treatment choice and investment in the information needed to select and provide optimal treatment. In this model, physicians can be negligent in one of two ways. They can deliberately provide suboptimal treatment (as in the classic model) or they

how autopsies of patients who died in a hospital revealed that one-third likely would have lived if properly diagnosed and treated); JEROME GROOPMAN, HOW DOCTORS THINK 24 (2007) (explaining evidence suggests that ten to fifteen percent of physicians' diagnoses are incorrect)

35. See Arlen \& MacLeod, supra note 18; Jennifer Arlen \& W. Bentley MacLeod, Torts, Expertise, and Authority: Liability of Physicians and Managed Care Organizations, 36 RAND J. ECON. 494 (2005).

36. This evidence on accidental error also highlights a deviation between negligence in daily life and the standard model that warrants attention: while certainly there are many instances of people who knowingly breach their duty of care - which is the only form of negligence possible in the standard model - there appear to be numerous instances of injurers who were uncertain whether their conduct constituted optimal care or not. 
can do so accidentally. Physicians can reduce, but not eliminate, their risk of providing suboptimal treatment accidentally by investing in expertise. ${ }^{37}$ To induce optimal care, tort liability needs to regulate both choices.

Analysis of this model has shown that tort liability for negligence can optimally regulate both choices. ${ }^{38}$ The standard of care (which is predicated on whether the physician selected the medically appropriate treatment) regulates treatment choice. Liability for failure to select the appropriate treatment will operate to induce informed physicians - those who are correctly informed about the patient's illness and available treatments - to select the optimal treatment if expected damages for knowing negligence equal or exceed the cost to the physician of providing optimal treatment. As in the classic model, super-compensatory damages will not induce excessive treatment, provided that courts do not err in setting the standard of care. These results are consistent with the classic model. ${ }^{39}$

Yet in this model, unlike the classic model, physicians are negligent in equilibrium, because providers face an omnipresent risk of selecting the suboptimal treatment accidentally. This risk of liability for accidental error operates to provide incentives for physicians to invest in expertise: the higher their level of expertise the lower their risk of error. Because physicians cannot avoid the risk of accidental error by investing optimally in expertise, liability for accidental error in effect imposes a form of strict liability on the physician's choice to invest in expertise..$^{40}$

Economic analysis of tort liability for accidental error differs from the results of the classic model in three ways. First, as already noted, physicians are negligent in equilibrium even when courts are assumed to accurately assess the standard of care. This result is consistent with the empirical evidence on physician error.

Second, optimal expected damages for accidental error are less than either the actual or the expected injury to the patient from suboptimal treatment. In order to optimally regulate expertise, expected damages for accidental error need to be predicated on the social benefit of expertise. The social benefit of expertise is increasing the likelihood that the patient receives optimal treatment instead of suboptimal treatment. This benefit is less than the harm caused from suboptimal treatment whenever either (1) physicians with optimal expertise nevertheless may provide suboptimal treatment or (2) the optimal treatment reduces, but does not eliminate, the patient's risk of suffering the same bad outcome as the suboptimal treatment.

37. Arlen \& MacLeod, supra note 35; see Arlen \& MacLeod, supra note 18; see also Jennifer H. Arlen, Economics of Tort Law, in 2 OXFORD HANDBOOK OF LAW AND ECONOMICS 41 (Francesco Parisi ed., 2017) (extending the model to other types of torts where determining optimal care is costly).

38. See Arlen \& MacLeod, supra note 35.

39. See id.

40. See id. 
Finally, the analysis shows that super-compensatory damages are inefficient because they cause physicians to over-invest in expertise. Because physicians cannot avoid the risk of liability by investing in optimal expertise - since they still might accidentally provide negligent treatment - physicians facing excessive damages will over-invest in expertise (including tests) to reduce their expected liability. ${ }^{41}$

Interestingly, altering the model of medical malpractice to reflect the insights of empirical analysis also reveals an aspect of "care" that has implications for the previously discussed debate over whether contracting over liability is optimal. Scholars employing the classic model of torts have claimed that states should allow medical providers to contract with patients over liability. They assert that contracting will result in the optimal imposition of liability, assuming that patients are informed about the costs and benefits of imposing liability by contract. ${ }^{42}$

One problem with this argument is that patients do not know precisely how liability will affect their risk of being harmed by medical error. Yet the preceding analysis reveals that this is not the only weakness in the argument for contractual liability. The preceding analysis reveals that contracting over liability would be inefficient even if patients were perfectly informed about the costs and benefits of imposing liability by contract.

Informed patients would not contract into liability even when they would benefit from tort liability because contractual liability benefits them less than tort liability. Contractual liability and tort liability are different because malpractice liability does not simply serve to induce physicians to take care that benefits a specific patient. Empirical analysis reveals that liability is needed to regulate a form of care-investment in expertisethat benefits many, if not all, of a physician's patients, by increasing her ability to diagnose and select appropriate treatment. ${ }^{43}$ Expertise, and thus the tort liability for accidental negligence that induces it, is a collective good.

Given this, contracting over liability would not be efficient even if patients did know the expected costs and benefits to them of liability imposed by contract because individual contracting over collective goods is not efficient. Physicians' incentives to invest in expertise depend on their ex-

41. See id.

42. E.g., Richard A. Epstein, Medical Malpractice: The Case for Contract, 1 AM. B. FOUND. RES. J. 87, 94-95, 149 (1976); Glen O. Robinson, Rethinking the Allocation of Medical Malpractice Risks Between Patients and Providers, 49 L. \& CONTEMP. PROBS. 173, 198 (1986). By contrast, health care economists tend to focus on analyzing the numerous inefficiencies plaguing health care contracts. See generally HANDBOOK OF HEALTH ECONOMICS (Anthony J. Culyer \& Joseph P. Newhouse eds., 2000); Joseph P. Newhouse, Economics of Health Insurance, in 3 THE NEW PALGRAVE DiCTIONARY OF ECONOMICS 872, 872-75 (Steven N. Durlauf \& Lawrence E. Blume eds., 2d ed. 2008).

43. Jennifer Arlen, Contracting over Liability: Medical Malpractice and the Cost of Choice, 158 U. PA. L. REV. 957, 992 (2010); Arlen \& MacLeod, supra note 18. 
pected liability to all of their patients. As a result, no one patient contracting for liability could provide a physician with optimal incentives. They all would need to impose liability together. When required to contract individually, each patient would have an incentive not to incur the cost of contractual liability in the expectation of free-riding on the liability decisions of others. Thus, even if each patient is better off if liability is imposed, each would have an incentive to select the lower cost "no liability" contract knowing that her individual decision would have little impact on the physician's incentives to invest in expertise. As a result, every patient could contract out of liability even if it is optimal for all to contract into it. ${ }^{44}$

\section{B. Evidence Prompting Expansion of the Potential Set of Options}

To predict behavior, a theoretical model also needs to accurately capture the material options available to people making the decisions being modeled. Empirical analysis can and has helped theoretical scholars identify situations where the standard theoretical model does not accurately predict behavior because it does not include all the actual options available. Empirical analysis has helped identify such situations both directly and indirectly, through evidence that actual choices diverge from predicted ones. This divergence has led theoreticians to reexamine the actual decision-making environment to identify options that people actually employ that the existing theory had not taken into account.

One area where empirical analysis has enriched theory indirectly by leading scholars to expand the option set employed in theoretical analysis is the economic analysis of takeover defenses. The threat of a hostile-and, for managers, potentially career-ending-acquisition represents an important mechanism for reducing managers' temptation to pursue personal interests at the expense of firm value. Yet Delaware law potentially mutes this disciplining effect by granting the board of directors considerable discretion to adopt defensive measures, such as the poison pill and effective classified board, which deter hostile acquisitions. ${ }^{45}$ Leading corporate scholars have called on Delaware courts to change the law. They claim that, although director control of ordinary business decisions is appropriate, shareholders, not directors, should have ultimate authority to decide whether to accept a takeover bid. Thus, courts should adopt a "shareholder choice" rule under which directors must grant shareholders the ability to

44. See Arlen, supra note 43 (discussing inefficiencies with contractual liability resulting from collective goods, adverse selection, and renegotiation); Albert H. Choi \& Kathryn E. Spier, Should Consumers Be Permitted to Waive Products Liability? Product Safety, Private Contracts, and Adverse Selection, 30 J.L. ECON. \& ORG. 734 (2014); Abraham L. Wickelgren, The Inefficiency of Contractually-Based Liability with Rational Consumers, 22 J.L. ECON. \& ORG. 168 (2006).

45. See Lucian Arye Bebchuk et al., The Powerful Antitakeover Force of Staggered Boards: Theory, Evidence, and Policy, 54 STAN. L. REV. 887, 928 (2002) (finding poison pills plus an "effective staggered board" is an effective takeover defense). 
vote on whether to pursue an acquisition and, following a positive vote, must remove any defenses that would impede the hostile action. ${ }^{46}$

The classic economic framework employed to support this analysis treats the threat of a hostile acquisition as shareholders' primary option for ameliorating agency costs. It also treats takeover defenses of the type that would be governed by a shareholder choice rule as management's only option for deterring a hostile bid (aside from simply maximizing firm value). In this framework, economic analysis would appear to support the claim that courts should require management to eventually submit all hostile bids to shareholders. ${ }^{47}$

One implication of this analysis is that adopting takeover defenses should reduce a firm's value. This suggests that informed shareholdersparticularly institutions - should place a higher value on corporations that do not permit the board to adopt and maintain takeover defenses over shareholders objections. Yet empirical evidence reveals that this is not necessarily the case. ${ }^{48}$

For example, consider evidence on the corporate contracts of firms that go public. Owners of firms going public have strong incentives to go public with corporate charter provisions that shareholders - specifically institutional shareholders - prefer in order to maximize the amount received from the initial public offering (IPO). Thus, one might expect companies going public to place restrictions on their boards' ability to adopt takeover defenses. Yet Robert Daines and Michael Klausner found that companies regularly go public with takeover defenses, such as classified boards and actual or shadow poison pills. Moreover, shareholders purchasing IPO shares do not appear to impose a penalty on firms that go public with takeover defenses. ${ }^{49}$

46. See, e.g., Lucian Arye Bebchuk, The Case Against Board Veto in Corporate Takeovers, 69 U. CHI. L. REV. 973, 976, 1027-28 (2002) (arguing that shareholders should be permitted to vote on whether to pursue a tender offer); Bernard Black \& Reinier Kraakman, Delaware's Takeover Law: The Uncertain Search for Hidden Value, 96 Nw. U. L. REV. 521, 559-63 (2002) (arguing that managers should be allowed to "Just Say No" temporarily but should not be allowed preclude a shareholder vote on a bid forever); see also Ronald J. Gilson, A Structural Approach to Corporations: The Case Against Defensive Tactics in Tender Offers, 33 STAN. L. REV. 819, 84865 (1981) (arguing for shareholder authority over tender offers).

47. See supra note 46.

48. The empirical evidence on the impact of takeover defenses on firm value is mixed. See, e.g., Michael Klausner, Empirical Studies of Corporate Law and Governance: Some Steps Forward and Some Steps Not, in THE OXford HANDBOOK ON CORPORATE LAW AND GOVERNANCE 184 (Jeffrey N. Gordon \& Wolf-Georg Ringe eds., 2018); Miroslava Straska \& H. Gregory Waller, Antitakeover Provisions and Shareholder Wealth: A Survey of the Literature, 49 J. Fin. \& QUANTITATIVE ANALYSIS 933 (2014).

49. Robert Daines \& Michael Klausner, Do IPO Charters Maximize Firm Value? AntiTakeover Protection in IPOs, 17 J.L. ECON. \& ORG. 83, 85-86 (2001) (finding that anti-takeover provisions are common at the IPO stage, and that about half the IPO firms studied adopted the strongest anti-takeover protections). 
In addition, there is evidence that the adoption and removal of clearday poison pills does not have a significant effect on firm value. ${ }^{50}$ In addition, classified board destaggering does not clearly increase in firm value. ${ }^{51}$ Both findings are inconsistent with the conclusions of the classic model that shareholders view these two takeover defenses as a threat to firm value. ${ }^{52}$ Finally, evidence showed that notwithstanding Delaware's decision to grant corporate boards broad authority to "just say no" to a hostile bid, the acquisitions market remained robust. ${ }^{53}$

This raises the question of why the evidence is not confirming the predictions of the theory. Scholars explored several potential explanations. ${ }^{54}$ Theorists have concluded that the standard model does not fully capture all the options available to both shareholders and to managers.

Specifically, the classic model does not capture the full set of options available to firms (and thus to shareholders) for reducing agency costs. Marcel Kahan and Edward Rock concluded that shareholders and firms have other options for muting managerial agency costs in the takeover context beyond restrictions on takeover defenses. ${ }^{55}$ These options include measures that reduce management's ability to resist an attractive hostile bid-such as requiring that a majority of the board be independent. They also include options designed to provide management with direct financial incentives to favor an acquisition - for example, through substantial grants of unvested options that vest upon a change of control. ${ }^{56}$ Firms and their shareholders have good reason to prefer such solutions to placing restrictions on boards' ability to defend against a hostile bid, to the extent that shareholders benefit from granting authority to the board to negotiate with raiders. ${ }^{57}$

50. Emiliano M. Catan, The Insignificance of Clear-Day Poison Pills, 48 J. LEGAL STUD. 1 (2019) (finding that removal of a poison pill does not increase firm value and adoption of a poison pill tends to be preceded by a fall in firm value but does not itself trigger a fall in firm value).

51. Emiliano Catan and Michael Klausner found that declassification has not had a significant effect on firm value. See Catan \& Klausner, supra note 4.

52. See Bebchuk et al., supra note 45 (finding that an effective classified board coupled with an actual or shadow poison pill is an effective impediment to hostile takeovers).

53. Marcel Kahan \& Edward B. Rock, How I Learned to Stop Worrying and Love the Pill: Adaptive Responses to Takeover Law, 69 U. CHI. L. REV. 871 (2002).

54. This evidence does not necessarily imply that shareholder choice is not optimal if special considerations affect corporate contracts at the IPO stage. See Michael Klausner, Institutional Shareholders, Private Equity, and Antitakeover Protection at the IPO Stage, 152 U. PA. L. REV. 755 (2003).

55. Kahan \& Rock, supra note 53, at 896-97 (arguing that managerial choice is less costly than many assert because shareholders have employed adaptive mechanisms, such as executive incentive compensation, to mute the agency costs associated with managerial choice); see Ellie G. Harris, Antitakeover Measures, Golden Parachutes, and Target Firm Shareholder Welfare, 21 RAND J. ECON. 614 (1990).

56. See supra note 55 .

57. See, e.g., Harry DeAngelo \& Edward M. Rice, Antitakeover Charter Amendments and Stockholder Wealth, 11 J. Fin. ECON. 329 (1983); Marcel Kahan \& Edward B. Rock, Corporate Constitutionalism: Antitakeover Charter Provisions as Precommitment, 152 U. PA. L. REV. 
The classic model also does not capture the full set of options available to managers for blocking acquisitions. Specifically, it does not incorporate the fact that, if shareholder choice were adopted, managers would still retain options to deter hostile bids-options that could be more costly to shareholders than are standard takeover defenses. Eric Talley and I concluded that shareholders might not want to block directors from employing standard takeover defenses because managers unable to protect their jobs through the use of poison pills would be motivated to employ other, more costly, measures to deter unwanted acquisitions - measures that would not be governed by a shareholder choice rule. Specifically, managers can deter acquisitions by embedding defenses in ordinary business transactions, governed by the business judgement rule (hereinafter "embedded defenses"). For example, they can place costly change of control provisions in contracts such as joint venture agreements, intellectual property licenses, customer service agreements, or debt contracts-provisions which impose substantial costs on the firm in the event of any change of control. Yet embedded defenses may deter friendly, as well as hostile, acquisitions. Shareholders thus would have good reason to conclude that they are better off when boards have authority to defend against hostile bids, provided that the firm adopts measure that incentivize managers to allow acquisitions to go through, than they would be under shareholder choice. ${ }^{58}$

These examples are only illustrative of the many ways that empirical analysis can, and has, enriched law and economics by spurring theorists to identify choice options that are material in the real world but had not been incorporated into theoretical models.

\section{From Rational Choice to Behavioral Law and Economics and Back Again}

A theoretical model also can only be relied on to predict outcomes and guide policy if it accurately captures the material features of the decision-making processes that people use systematically when making decisions. Determining how to model human decision-making may be the most important challenge currently facing law and economics; it is a challenge that empirical analysis is playing a vital role in addressing.

Classic law and economics assumes that people employ rational choice theory. This assumption appears to be valid in some situations but

473, 484-88 (2003) (arguing that shareholders may get better deals when directors have full authority to negotiate that includes authority to reject a bid).

58. Jennifer Arlen \& Eric Talley, Unregulable Defenses and the Perils of Shareholder Choice, 152 U. PA. L. REV. 577 (2003); see also Marcel Kahan \& Michael Klausner, Antitakeover Provisions in Bonds: Bondholder Protection or Management Entrenchment?, 40 UCLA L. REV. 931, 954 (1993) (discussing mangers' defensive use of debt covenants with penalty-imposing change of control provisions); Edward B. Rock, Controlling the Dark Side of Relational Investing, 15 CARDOZO L. REV. 987, 1006-07 (1994) (discussing the issuance of sweetheart preferred stock as a takeover defense). 
not in others. A growing body of empirical and experimental evidence reveals that people often do not make decisions consistent with rational choice theory. Instead, they deviate in systematic ways from the predictions of rational choice. Examples of systematic deviations include evidence on the endowment effect, preferences for fairness, hindsight bias, and egocentric biases. ${ }^{59}$

Many theorists have responded by developing theoretical behavioral law and economics analyses that take these biases and heuristics into account, developing normative theories that are premised on the assumption that people making decisions in the real world always exhibit the biases and heuristics found in the laboratory experiments. ${ }^{60}$ This effort to expand law and economics theory to take into account new evidence on human decision-making is producing important contributions.

Yet scholars ploughing these fertile fields face an enormous challenge: at present, scholars generally cannot predict whether and when many of the biases and heuristics will affect decision-making in any particular realworld situation. This is the case for three reasons.

First, we do not yet fully understand the root causes of many biases and heuristics. As a result, we often do not know (and cannot predict) their domain. Indeed, many of the biases that scholars regularly treat as nearly omnipresent-such as the endowment effect-are present in some situations and not in others. Moreover, they are not present in some situations where existing theory predicts that they should be manifest. ${ }^{61}$

Second, and related, experimental results cannot necessarily be relied on to predict real world decisions. There are many reasons for this. Two are particularly important. The first is that people appear to use multiple, interacting, decision-making programs when making decisions. One type is conscious and more deliberative and rational. The other type is non-conscious or intuitive decision-making programs that are often impacted by

59. See, e.g., Richard H. Thaler, The Winner's Curse: Paradoxes AND ANOMALIES OF ECONOMIC LIFE (1992); Linda Babcock et al., Biased Judgments of Fairness in Bargaining, 85 AM. ECON. REV. 1337 (1995); Ernst Fehr \& Simon Gächter, Altruistic Punishment in Humans, 415 NATURE 137 (2002); Elizabeth Hoffman \& Matthew L. Spitzer, The Coase Theorem: Some Experimental Tests, 25 J.L. \& ECON. 73 (1982); Daniel Kahneman et al., Fairness as a Constraint on Profit Seeking: Entitlements in the Market, 76 AM. ECON. REV. 728 (1986); Daniel Kahneman et al., Experimental Tests of the Endowment Effect and the Coase Theorem, 98 J. POL. ECON. 1325 (1990).

60. For an introduction to this literature see, for example, RESEARCH HANDBOOK ON BeHAVIORAL LAW AND ECONOMICS (Joshua C. Teitelbaum \& Kathryn Zeiler eds., 2018); THE OXFORD HANDBOOK OF BEHAVIORAL ECONOMICS AND THE LAW (Eyal Zamir \& Doron Teichman eds., 2014); and EXPERIMENTAL LAW AND ECONOMICS (Jennifer H. Arlen \& Eric L. Talley eds., 2008). See also DANIEL KAHNEMAN, THINKING, FAST AND SLOW (2013).

61. See, e.g., Jennifer Arlen, The Future of Behavioral Economic Analysis of Law, 51 VAND. L. REV. 1765 (1998); Kathryn Zeiler, Cautions on the Use of Economics Experiments in Law, 166 J. InSTITUTIONAL \& THEORETICAL ECON. 178 (2010); see also Kathryn Zeiler, What Explains Observed Reluctance to Trade? A Comprehensive Literature Review, in RESEARCH HANDBOOK ON BEHAVIORAL LAW AND ECONOMICS, supra note 60, at 347. 
biases, heuristics, and emotions. ${ }^{62}$ The interaction between these programs is context dependent. Thus, decision-making in the lab may differ from decision-making in the real world depending on whether features of the real world context cause the more deliberative processes to dominate. ${ }^{63}$ In addition, and related, both theory and evidence suggests that people's inclination to exhibit certain deviations from an egocentric rational choicesuch as the endowment effect and fairness preferences-is affected by whether they decide autonomously (as in many laboratory experiments) or within an institution that enables them to spread responsibility for the decision - such as agency relationships or voting. Experiments have found that agency relationships and voting can mute, if not eliminate, both the endowment effect and the preference for fairness. ${ }^{64}$ This is important because many, if not most decisions in the market context involve agents; organizational decision-making is dominated by responsibility-spreading institutions, including voting.

Indeed, there is evidence that people strategically employ institutions in order to debias. When faced with a situation where a bias or heuristic (for example, regret aversion or fairness preferences) might cause them not to maximize their financial welfare, people appear to engage in strategic bias self-management. They employ institutions and other measures that spread responsibility in order to mute the bias or heuristic, thereby enabling them to make the choice that serves their narrow self-interest, consistent with rational choice theory. ${ }^{65}$

Thus, empirical, experimental, and neuro-economic analysis has greatly enhanced our understanding of human decision-making. In so doing, it has revealed the need to alter the classic models in law and economics. But these analyses also have revealed that human decision-making is complex. Our understanding of it is still evolving. This creates challenges for those seeking to develop models that can reliably predict how people will respond when making a range of decisions. A combination of theory,

62. See, e.g., Jennifer H. Arlen \& Eric L. Talley, Introduction to EXPERIMENTAL LAW AND ECONOMICS, supra note 60, at ix.

63. See, e.g., KAHNEMAN, supra note 60; Colin Camerer et al., Neuroeconomics: How Neuroscience Can Inform Economics, 43 J. ECON. LIT. 9 (2005); see also Arlen \& Talley, supra note 62 (describing the interaction between nonconscious and conscious decision-making and its implications for experimental and behavioral law and economics).

64. See, e.g., Arlen \& Tontrup, supra note 5; Bartling \& Fischbacher, supra note 5.

65. Studies providing examples of strategic bias self-management include: Arlen \& Tontrup, supra note 5 (showing how people use agents and voting to mute the endowment effect triggered by regret aversion); Jennifer Arlen \& Stephan Tontrup, Strategic Bias Shifting: Herding as a Behaviorally Rational Response to Regret Aversion, 7 J. LEGAL ANALYSIS 517 (2015) (showing how people strategically access information on decisions of others when they have reason to believe others traded when it was optimal to do so); Bartling \& Fischbacher, supra note 5 (use of agents to make unfair decisions); John R. Hamman et al., Self-Interest Through Delegation: An Additional Rationale for the Principal-Agent Relationship, 100 AM. ECON. REV. 1826 (2010) (same); Adam Hill, Does Delegation Undermine Accountability? Experimental Evidence on the Relationship Between Blame Shifting and Control, 12 J. EMPIRICAL LEGAL STUD. 311 (2015) (same). 
experimental evidence, and data-driven empirical analysis will enable scholars to develop more robust theories of human decision-making to serve as a foundation for future theoretical analysis.

\section{Conclusion}

Theoretical law and economics has benefited from insights provided by empirical analysis throughout its history. Empirical analysis has repeatedly helped scholars identify situations where an existing theoretical model needed to be revised. Empirical analysis has prompted reform both directly and indirectly. Empirical analysis has spurred change indirectly when it produces robust results that are inconsistent with the theoretical predictions. These results, when confirmed by multiple valid studies, provide an important impetus for scholars to reexamine the foundations of their models in order to identify the facets of the decision-making environment as set forth in the model that are inconsistent with the actual decisionmaking environment. Empirical analysis has induced changes directly by providing evidence about actual decision-making environments (or actual decision-making processes) that differ materially from those currently favored by theorists. This interaction between theory and empirical analysis is an exciting and ongoing source of new insights. It is vital to theory's ability to develop models that enable scholars to reliably describe and predict how people respond to legal rules in the real world.

The insights gleaned from this interaction does present challenges. First, as theoretical models have gotten more sophisticated-for example, incorporating asymmetric information and incomplete contracting-they also have gotten more mathematically complex. This adds to the challenges of both developing new theoretical frameworks and presenting the analysis in a way that is generally accessible. Second, as theory has increasingly sought to incorporate insights about human decision-making, the limitations of our existing understanding of human behavior has become a source of uncertainty as to the validity of theoretical law and economics models as well. This is less of a concern in those areas where it appears that people tend to engage in more deliberative decision-making, undistorted by biases and heuristics. Yet much remains to be done to determine when people's decisions can be appropriately described using rational choice theory and what other decision-making functions they employ when rational choice is inapposite.

In the meantime, normative theorists can best respond to the various sources of uncertainty about the validity of their models by openly assessing whether their results are robust to alternative plausible assumptions. Theorists may do so by examining either the decision-making environment or the decision-making processes employed by the decision- 
makers. They also should be appropriately circumspect about their normative conclusion when their results that depend heavily on assumptions that may prove not to be correct. Empiricists can assist this effort by continuing to help us better understand how people make decisions in general, and how they actually respond to legal rules in particular. The strength and future of law and economics lies in this dialectical interaction. 